\title{
Interannual Variability of Stormy Day Over Turkey
}

\section{Türkiye’deki Furtınalı Günlerin Yıllararası Değişkenliği}

\author{
Yusuf Fırat KURTULUŞ ${ }^{1}$ (อ, Zahide ACAR ${ }^{1}$ (1) \\ ${ }^{1}$ Çanakkale Onsekiz Mart University, Faculty of Arts and Sciences, Department of Geography, Çanakkale, Turkey
}

ORCID: Y.F.K. 0000-0002-6387-996X; Z.A. 0000-0002-9174-0447

\begin{abstract}
The effects of climate variability are seen in many areas of the globe. In addition to the changes experienced in climates for many years, the variability in climate elements due to the effects of climate change in recent years is critical. In this study, spatial and temporal changes of the year to year experienced variability and trends in storm records in Turkey were examined. Also, atmospheric teleconnections that control storm frequency were examined within the scope of the study. According to the results of the study, significant reductions in recent years in the frequency of storm events are being experienced across Turkey. Stormy days show statistically significant upward trends in the interior and eastern half of Turkey. All coastal regions of Turkey, especially the western coasts and terrestrial areas in the eastern parts of the Mediterranean region experienced statistically significant downward trends. In Turkey, the NAO's activity on the number of stormy days is quite evident in winter. NCP and frequency of storms is characterized by significant positive correlations in eastern Turkey. When evaluating the relationships between Turkey's storm frequency and Atmospheric oscillations, one can say that NAO and AO are atmospheric oscillation indices that best explain storm frequency across the country.
\end{abstract}

Keywords: Turkey, stormy day, NAO, AO, NCP, variability

Submitted/Başvuru: 29.06.2020 • Revision Requested/Revizyon Talebi: 08.09.2020 • Last Revision Received Son Revizyon: 30.10 .2020 • Accepted/Kabul: 20.11.2020 • Published Online/Online Yayın: 10.06.2021

Corresponding author/Sorumlu yazar: Zahide ACAR / zacar@comu.edu.tr

Citation/Atıf: Kurtulus, Y. F., \& Acar, Z. (2021). Interannual variability of stormy day over Turkey. Cografya Dergisi, 42, 19-31. https://doi.org/10.26650/JGEOG2020-0055 


\section{INTRODUCTION}

Global climate change and climate variability are influenced by different variations in each region of the world. Climate change and climate variability according to the specific locations of the places cause deviations from their long-term average values of climate elements such as rainfall, temperature, wind. This deviation is associated with drought in some areas, while in some areas it is associated with sudden and severe weather events. In general, climatic variability directly causes climate elements to deviate from their average values or to occur well above or below normal values (extreme weather events).

Wind is defined as moving a parcel of air horizontally from one place to another due to the pressure difference between locations. Wind develops depending on many parameters such as atmospheric circulation, pressure difference, topography, frontline properties. The speed, direction and frequency vary depending on these characteristics. Wind gets different definitions based on its speed. The winds leading to the storm event throughout Turkey are north-oriented Poyraz and southwest-oriented Lodos winds.

Wind, which is an important element of climate in the formation mechanism of storms, is the lead actor. According to the World Meteorological Organization (WMO) (WMO, 2013) and the International Panel on Climate Change (IPCC) reports (IPCC, 2007), the Mediterranean basin is among the areas most affected by climate change.

Turkey is one of the driest areas in all seasons, dominated by subtropical pressure conditions in the south, the rainy climate of Central-Western Europe, influenced by Western systems in the north, and continental climates in the west of Asia. Due to Turkey's geographical position in the subtropical zone in the western part of the continent, it is located in the Mediterranean macroclimate. In Turkey there are many climates of transitional nature.

In the global climate change process, the variations in the average values of climate elements (wind) affect the force and frequency of weather events (storm). According to the Beaufort scale (WMO, 2016; Sanho, 2009), windy weather conditions in which the wind speed blows at least ten minutes and above at a rate of 17.2-20.7 m/s (storm) and 20.8-24.4 m/s (strong storm) are defined as storms. Days with wind at this speed are called stormy days. Storms bring with them severe weather events. These events usually take the form of heavy rain, hail, snow, lightning and thunder.
In general, the variability tendency of storms differs according to the area differences of the studies. There is a strong relationship between the spatial distribution of storm events and the topography in the Mediterranean region. In the Mediterranean region, there is a significant relationship between precipitation and storm intensity (Galanaki et al., 2018). In northern Europe, increases in stormy days were generally evident from the 1960s to the 1990s, with calmer conditions beginning to take effect after the 1990s (Alexandersson et al. 1998; Barring and von Storch 2004). Storm events in the Netherlands show a reduction rate of $5 \%$ and $10 \%$ between the years 1962 and 2002 (Smits et al., 2005). The effectiveness of calm conditions is quite high in the inner parts of Europe (Matulla et al., 2008). For example, the number of stormy days in Poland does not include a marked variability in the prolonged period (Bakowska, 2003). The study for the western Black Sea indicated that while there had been increases in Storm incidents up to the 1980s and 1990s, there had been a trend towards calmer weather from the 2000s (Valchev et al., 2012).

Most stations in Turkey (73\%) have average wind speeds of between 1.6 and $3.3 \mathrm{~m} / \mathrm{h}$ over a 32 -year period. During the period from 1975 to 2006, in $72 \%$ of stations, on average, annual wind speeds had a tendency to decrease. Decrease trends are statistically significant at 0.05 level for $62 \%$ of stations. I ncreasing trends were detected in only $16 \%$ of 206 stations. The same study concluded that changes in wind speeds in Turkey are most strongly related to changes in overall atmospheric circulation and air temperature (Çelik and Cengiz, 2014). Climate change has been cited in many studies as the reason for increased surface and lower atmosphere air temperatures across the Mediterranean Basin. Due to this increase in temperatures, evaporation is also predicted to increase and the hydrological cycle to change. Thus, the number and severity of storms and tornadoes may increase in Turkey (Türkeş and Şahin, 2018).

According to Mann-Kendall test statistics, when the storm events experienced throughout Turkey are evaluated, significant reductions in storm events have prevailed since 1990. As long annual storm records are examined, there were 103 storms (10 days/year) in the period 1990-1999, 87 storms (9 days/year) between 2000 to 2009 years, and 52 storms (6 days/year) in 2010 and later. There is a decreasing tendency towards s torm events in Turkey. In some areas increases in the numbers of storms are quite strong.

Inter-annual variability in climate elements or the existence of different extreme values by years are generally explained by associating with climate change and climate variability. 
According to previous studies (Stroe and Tatui, 2005; 2011 and Qu et al., 2012; etc.) teleconnections and extreme weather events have a large role in variability in climate elements and differences in extreme values by years. These are climate anomalies that have a periodic character.

The North Atlantic Oscillation (NAO) is characterized by the disparity between normalized sea-level pressures reflecting high pressure in the Azores and low pressure in Iceland. NAO index is the primary mode for atmospheric instability in the North Atlantic (Hurrell, 1995). Major positive index spans in England and Northern Europe lead to powerful westerly winds. Western winds move farther south in negative index spans, allowing the air motions to increase throughout the Mediterranean basin. North Atlantic Oscillation (NAO) regulates climate change, especially in winter, from the east coast of America to Siberia and from the $\mathrm{N}$ orth P ole to the subtropical Atlantic (Hurrel et al., 2001).

Storm frequency and storm location are influenced by largescale disconnection patterns, such as North Atlantic Oscillation (NAO) and North Caspian Pattern (NCP)/East Atlantic West Russia (EAWR) periods, as reported in studies for the eastern Mediterranean basin (Kutiel and Benaroch, 2002). Throughout the Western and Central Mediterranean, the occurrence and severity of cyclones has declined during the past decade. The explanation for this downturn is that NAO's positive period happens more often as the storm course travels north (Nissen et al., 2010; Trigo, 2006; Alpert et al., 2004; Maheras et al., 2001). Under different models of climate change (Marcos et al., 2011; Raible et al., 2010), it indicates that the circulation process correlated with NAO's positive period may arise more often as the climate warms. It would cause major modifications to aspects of nature, such as precipitation and storm frequency.

Simultaneous and/or contrasting changes in climates in distant regions of the earth are referred to in the literature as "teleconnection" (Hurrel et al., 2003). The variations in average airflow and stormy frequency due to North Atlantic Oscillation (NAO) fluctuations affect temperature, precipitation, heat flows and wind speeds in the Atlantic-Europe region. Studies conducted for many regions of Europe show the regional effects of the NAO. For example; Central Europe, Scandinavia, Greenland etc. In the sea of Greenland, there is generally a negative correlation between sea surface temperature and wind speed, a positive correlation between ice cover, sea surface temperature, wind speed and NAO (Qu et al., 2012). About 80\% of stormy days in central Europe are linked to Western flows. It was determined that storm events in central Europe primarily occur during the moderately positive NAO phase, while in the strongly positive NAO phase ( $6.4 \%$ of all days) more than $20 \%$ of storms occurred. A storm occurs over Central Europe during about 10\% of the day with a high positive NAO index. The path in which cyclone systems associated with storms over Central Europe are most often effective is observed along the line stretching from the North Atlantic to the British Isles, the North Sea and southern Scandinavia to the Baltic Sea. The average density of these systems typically reaches its maximum near the British Isles (Donat et al., 2010). While temperature anomalies in Romania are directly associated with NAO phases, there is an indirect relationship between the shape of precipitation and the NAO. A close relationship exists between the negative phase of NAO index values and coastal storms. Therefore, high annual average wind speed can be explained by negative phases of NAO (Stroe and Tatui, 2005; 2011).

High pressure occurs in latitudes of 80-90 degrees and extreme pressure in the Atlantic and North Pacific while the Arctic circulation (AO) is in positive mode. Jet winds are stronger in this process, and adopt a waveless motion. Therefore, in more northern latitudes, jet winds and storms pursue the path. It is facing fewer harsh winter seasons than in Europe, North America and Asia. High pressure occurs in Siberia and high latitudes while $\mathrm{AO}$ is in negative mode, and low pressure spreads into the Caribbean and North Pacific. During this process, the jet winds intensify and, with a fluctuating motion, the raids of polar air into middle latitudes increase. Polar air is pushed through more southern latitudes, resulting in large temperature fluctuations.

AO is similar to NAO. The Arctic oscillation pressure anomalies at sea level, and the North Atlantic oscillation pressure anomalies at sea level function more in unison. Such two oscillations converge in time series (Hurrell, 2000).

The effects of the North Sea- Caspian Pattern (NCP) teleconnection pattern are quite evident on the climate in the Mediterranean basin. The combination of an increasing cyclonic anomaly circulation pattern over the North Caspian Sea region and an increasing anticyclonic circulation pattern effect on the North Sea region is an evolving atmospheric disconnection. In the positive phase of NCP, the increasing northeast anomaly circulation causes negative temperature anomalies. The effects of teleconnection patterns or their correlations with climate elements include different results by region to region (Kutiel et al., 2002; Ghasemi and Khalili, 2008). For this reason, examining the effects of all teleconnection patterns on climates is important for understanding climate variability and extreme climate events. 
Turkey is in the domain of many teleconnection patterns, both direct and indirect (delayed) due to its geographical location. Turkey is in the direct domain of important remote link patterns such as the North Atlantic Oscillation (NAO), the Arctic Oscillation (AO) and the North Sea-Caspian pattern (NCP). Studies investigating the effects of teleconnection patterns on climate are numerous. These studies are generally based on atmospheric connections that have an effect on Turkey's precipitation and temperature parameters (Ünal et al., 2010; Türkeş and Erlat 2008; Baltacı et al., 2017 etc.). The results of these studies support each other. For example, when NAO is in a positive phase, it causes the temperatures to be below the normal season's and the precipitation amounts to be reduced in Turkey. When NAO was in the negative phase, it caused temperature values to rise and precipitation amounts to increase. The relationship between NAO and precipitation and temperature has shown a negative correlation, indicating an inverse relationship in all studies (Türkeş and Erlat, 2008; Türkeş and Erlat, 2005).

Storm events have a complex structure. I t can also vary greatly on a micro-scale according to the characteristics of the space or, in a region experiencing a transitional climate, variations in the average values of climate elements can lead to major changes in the forces and frequencies of storm events.

Studying the spatial and temporal characteristics of storms, explaining the atmospheric circulations that affect storms, is the main subject of the study. The aim of the study is to identify areas with an increasing trend of storms and extreme storm events. It is thought that this study will contribute to prevention and planning issues in areas where storm events are effective. It is expected that the study will contribute to many studies in order to prevent the negative effects of storms. Within the scope of the study, the connection between atmospheric oscillation indices and the Turkish storm frequency was attempted to be explained. For this purpose, indices of the North Atlantic Oscillation (NAO), the Arctic Oscillation (AO) and the North Sea-Caspian pattern (NCP) were used .

\section{DATA AND METHOD}

Daily wind data provided by the Turkish state Meteorological Service was used in the scope of the study. Data from 206 meteorological stations cover the period 1960-2018. From the Daily wind speed data of the number of stormy days were obtained. The study investigated the effects of atmospheric oscillation indices on Turkey's storm frequency. For this purpose, NAO (https://crudata.uea.ac.uk/cru/data/nao/), AO (https:// www.ncdc.noaa.gov/teleconnections/ao/), and NCP (https:// crudata.uea.ac.uk/cru/data/ncp/) indices have been utilized.

The Kendalls Tau method was used to determine the nature and magnitude of variability in wind speed data.

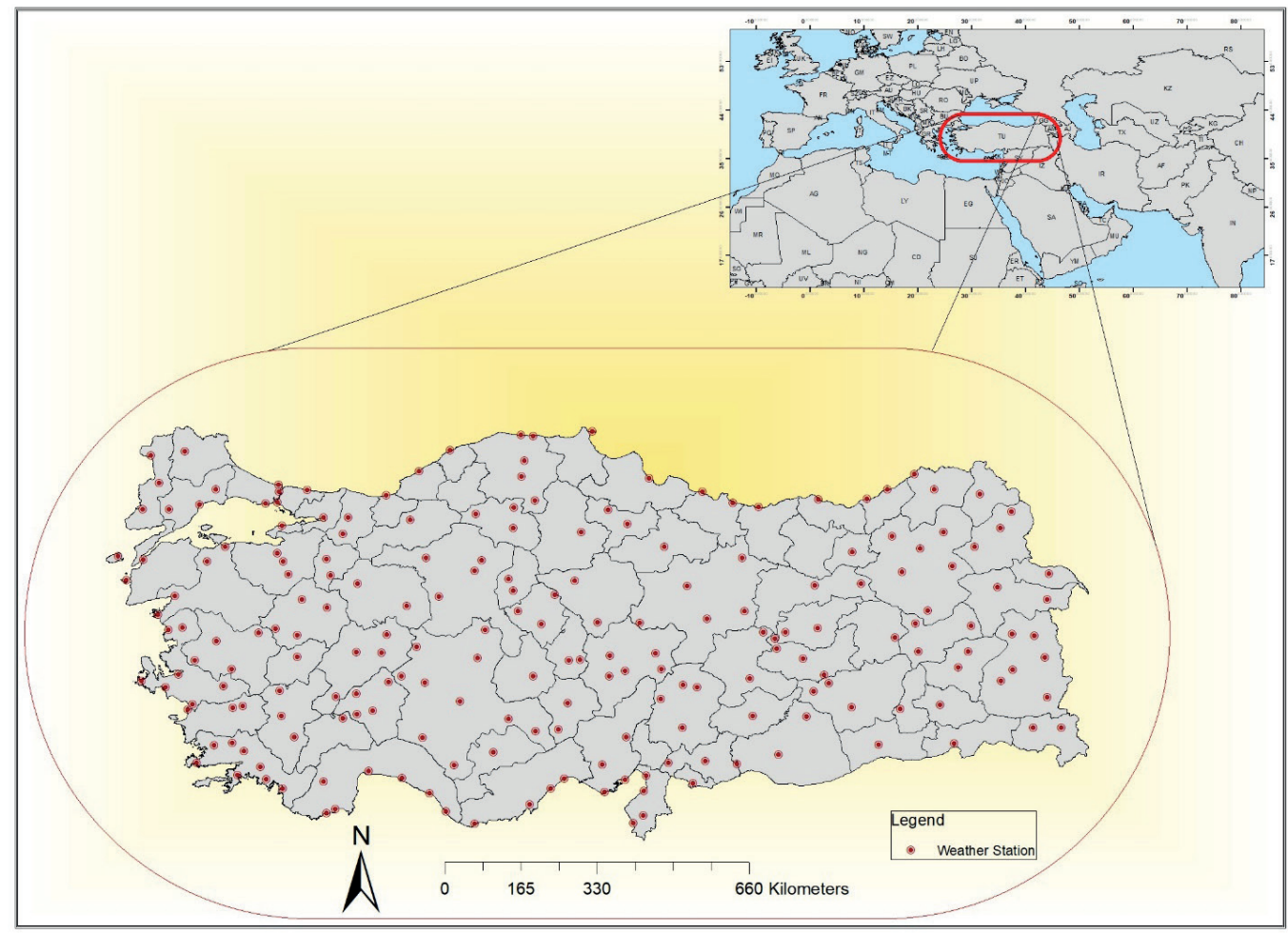

Figure 1. Working area and weather station in Turkey. 
According to the Mann-Kendall test, $\tau$ is a value that indicates the magnitude of the observations. The $P$ statistic is calculated by;

$$
P=\sum_{i=1}^{N-1} n_{i}
$$

The Mann Kendall test statistic $\tau$ is calculated as follows;

$$
\tau=\frac{4 P}{N(N-1)}-1
$$

The value of the test statistics is normal for all $\mathrm{N}$ values, larger than 10. The significance test is calculated as follows;

$$
\tau_{(t)}=0 \pm t_{g} \frac{(4 N+10)}{9 N(N-1)}
$$

Where $t_{g}$ value is the requested probability point in the normal distribution (two sided). A positive value of $\tau$ indicates an upward trend, a negative value of $\tau$ indicates a downward trend (Mann, 1945; Kendall, 1975). This study focuses on observed trends in daily wind data in Turkey.

For the relationship between atmospheric indices and stormy days, the Pearson correlation test was applied under the SPSS package program. The nature and magnitude of the relationships between storm and Atmospheric oscillation indices were determined by the Pearson correlation coefficient. The magnitude of Pearson's correlation coefficient $(-1 \leq \mathrm{r} \geq+1)$ gives information about the relationship. The significance of statistical correlation coefficients in storm data and atmospheric oscillation indices were controlled by the Student $t$ test.

\section{RESULTS}

The temporal variability of the number of stormy days in Turkey varies spatially. In general, the numbers of stormy days showed a statistically significant decreasing trend in the western and coastal areas of Turkey, while the inland regions and the eastern half showed a statistically significant increasing trend. The regions where the storm increase is experienced mostly correspond to the areas where the wind is channeled by topographic effects. Furthermore, Turkey's coastal areas during the winter season will remain under the influence of mid-latitude depression. Especially in the rainy period, the storm conditions that develop due to the characteristics of the mid-latitude low pressure centers also increase. The difference of spatio-temporal variability in storm frequency can be explained by the global climate change process, geographical location characteristics of Turkey and the effects of atmospheric oscillation patterns. Spatial variability in storm frequency depends on the geographic location and topography characteristics of the space, as well as the effects of atmospheric oscillation patterns. Temporal variability in storm frequencies is linked to variability in climate elements and atmospheric circulation conditions. The number of stormy days in Turkey during the years 1990-2018 with linear regression is present in Figure 2. There has

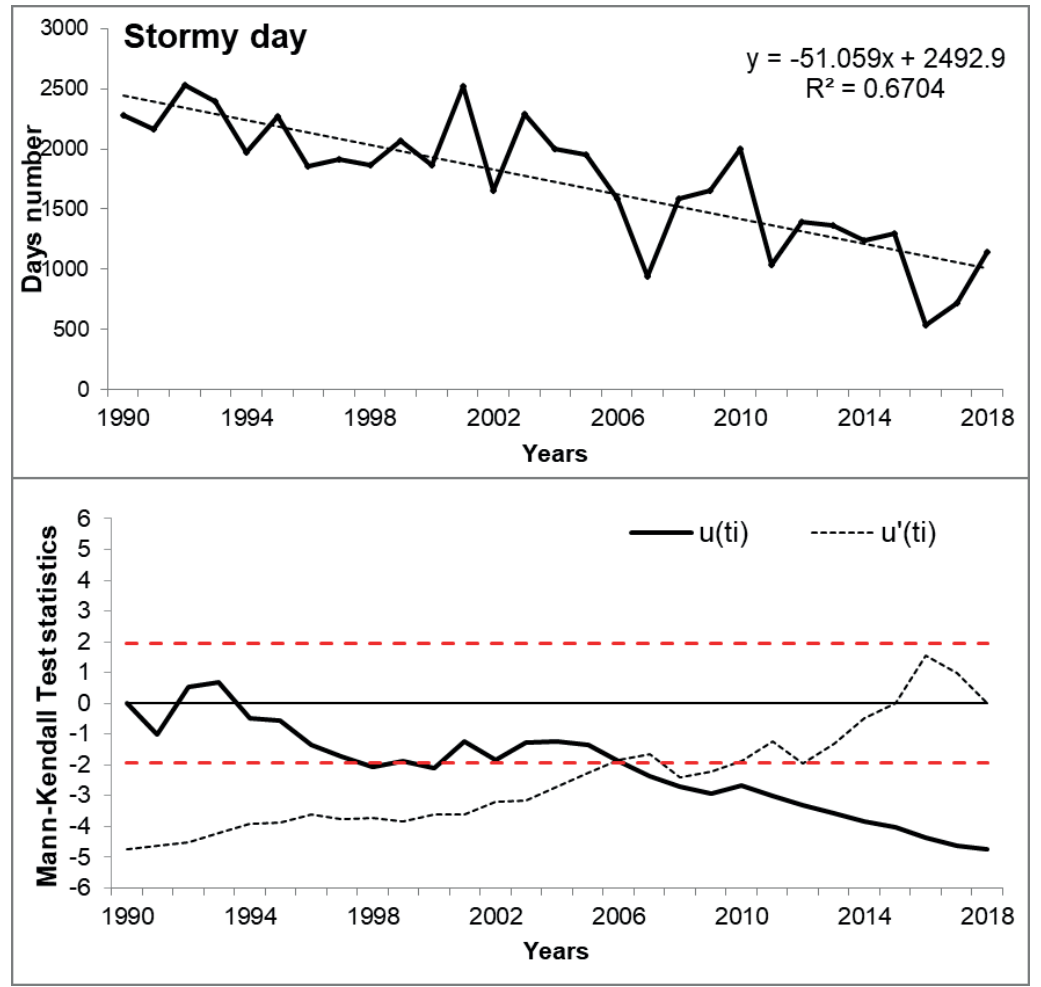

Figure 2. Temporal variability observed the total number of stormy days in Turkey during the 1990-2018 period. 
been generally decreasing rates in stormy day frequency. By the mid-2000s the stormy days began to increase progressively. In 2007, there were quite a few storm events in Turkey.. With this period, the inter-year fluctuation in the number of storms is more evident. As in Figure 2, there is a statistically decreasing trend at the beginning of 2006 (Figure 2).

With the effects of climatic change, increases in air temperatures, variations in precipitation and different warming tendencies of the surfaces, and changes in the wind climatologies of these areas directly affect the severity and frequency of storm events.

In general, there is a relationship between storm events, temperature and precipitation. There is high correlation between the spatial distribution and topography of storm events and between precipitation and storm intensity in the Mediterranean region (Galanaki et al., 2018).

A statistically significant decreasing trend is quite intense in the coastal region of Turkey. However, statistically significant increasing trends are evident in large inland areas. In Turkey, storms are generally intense in coastal areas. As a result of global climate change/variability, decreasing trends in the frequency of storms are observed in coastal areas due to the differentiation of pressure centers that are determinant on storm activity and less frequent depressions. Storm frequency in inland parts of Turkey is affected by local thermal circulation cells that develop due to topography characteristics and water assets in some special areas (such as; dams, lakes, ponds). The number of stormy days include a statistically significant upward trend, especially in the interior and in the eastern part of Turkey. In general, storm events are dominated by statistically significant reduction trends in all coastal areas, especially on the western coast and in the east part of the Mediterranean region and southeastern part of Turkey (Figure 3).

Climate change is generally associated with drought in areas dominated by the Mediterranean climate (Xoplaki, 2002). In Turkey, the decreasing trend in stormy events in the Mediterranean coastline, Aegean coast and Marmara region shows similar characterictics to that in Galanaki et al. (2018).

Decrease trends in precipitation in the coastal zone of Turkey (etc. Türkeş, 1996) and decrease trends in stormy day frequencies are similar to each other (Kurtuluş and Acar, 2019).

Significant increases in storm frequency in the inner regions, especially in and around Elazığ, can be explained by the topographic features of the region and land use changes (impact of dams). The increase in temperatures and the increase in evaporation rates from the later dam lakes (Atatürk Dam and

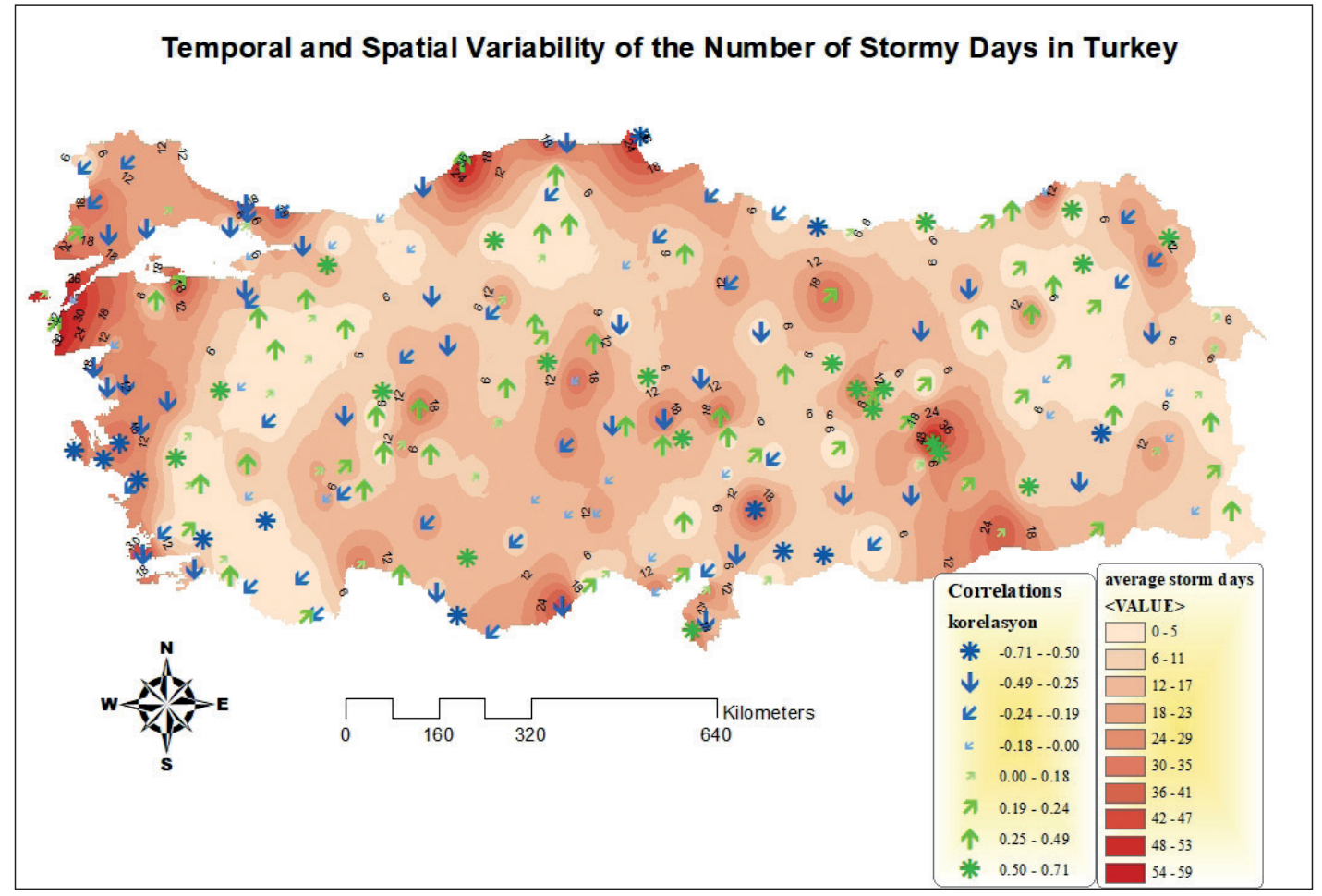

Figure 3. Temporal and Spatial Variability of the Number of Stormy Days in Turkey. 
Keban dam) after the 1990s has led to changes in the hydrological cycle of this area and surroundings. It is thought that the land use change may lead to increased storm events. Many studies around dam lakes (Atatürk Dam and Keban dam) show similar results. According to the results of these studies, increasing trends were observed in maximum, minimum and average temperatures in all months after the construction of the dams. There were increasing trends in maximum, minimum and average temperatures and wind speed, while there was no trend in evaporation and precipitation (Bacanlı and Tugrul, 2016; Bulut et.al, 2008; Kum, 2016).

The geographical features of Turkey have direct and indirect effects on storminess. The temporal and spatial variability of the numbers of stormy days show different variations over short distances. The differences in short distances are quite high in the temporal variability of the number of stormy days. The middle of the Black Sea region especially shows a statistically decreasing trend, while the Eastern Black Sea region shows a statistically significant upward trend. This is because the topographic structures of the two sections (the distance of the mountains to the sea) are different.

It is necessary to evaluate multiple parameters together to interpret and/ or make sense of the state and/ or variability of storminess in a region. Adhering to a single parameter the actor on the storminess status of areas or regions that have microconditioning characteristics may not be able to determine the parameter. Adhering to a single parameter may not be able to determine the actor's parameter on the storminess of areas or regions displaying microclimate properties. The analysis of the effects of all parameters are important for understanding the periodic characteristics of the storminess situation, the places and times where it shows extreme values.

\section{Correlations between NAO and storm}

During winter storms the clearest connections between Turkey and the NAO index were observed. In Turkey, the number of storms and in almost every area the statistically important negative correlations with the NAO are controlled. Negative correlations are concentrated in the western half of the country. When the NAO index is in a negative period, the atmosphere impacts precipitation and storms in western Turkey. The direction of movement of Atlantic-origin cyclones in turkey is generally westerly and southwesterly.

The relationship between the long winter (DJFM) and the long winter storm frequency and NAO index weakens from the east of Turkey. The effect of the NAO index on storminess decreases from east to west of Turkey (Figure 4). The effect of the NAO index on storm frequency is continuous in the western half of Turkey. Precipitation and storminess increase in Turkey during periods of negative NAO index. Especially in the winter season, this effect increases quite significantly. Future variability in the NAO index will also closely affect the state of precipitation and storminess of Turkey.

\section{Correlations between NCP and storm}

The results of the remote contact model for the NCP, such as NAO, on the Mediterranean basin climate are evident. The consequences of patterns of remote interactions or their associations with environment elements provide specific findings by area (Kutiel et al., 2002). Positive differences between the NCP and storm occurrence are also statistically important. It is found that the positive correlations in the shape of a northeastern groove relate in particular to the Eastern Mediterranean and subsequently to eastern Anatolia. The explanation for this is because a groove in the upper atmosphere in north Cyprus and the Eastern Mediterranean during the successful NCP years in the winter (Ghasemi and Khalili, 2008) and this groove provides a perfect atmospheric climate for the rise in storm events. A statistically important positive and negative associations were found in the South and Central Anatolian Mediterranean coastal belt of Turkey in particular. In the Black Sea area and in the North of the Marmara zone, statistically meaningful correlation is almost never found. The NCP index is a remote link with significant effects on storm variability (upward trend) in the south and southeast of Turkey (Elazığ and its surroundings) (Figure 5).

In areas where there are statistically significant positive correlations, storminess increases depending on the presence of the area where the atmospheric trough settles. During periods when the NCP index is negative, the storm frequency decreases in the south and southeast of Turkey, which is under the influence of the area where the atmospheric ridge develops. In this way, it is possible to explain the variability of storminess in these regions (the tendency to decrease in and around the Gulf of Izmir).

This ties some of the variation in surface temperatures, winds and therefore flows to NCP in the Aegean Sea (Kutiel et al., 2002; Gündüz and Özsoy, 2005). They describe the irregular circulation by the NCP index of air temperature and precipitation, especially in the Balkans and the east Mediterranean area (Kutiel 


\section{Correlation Between Annual Nao and Stormy Days}

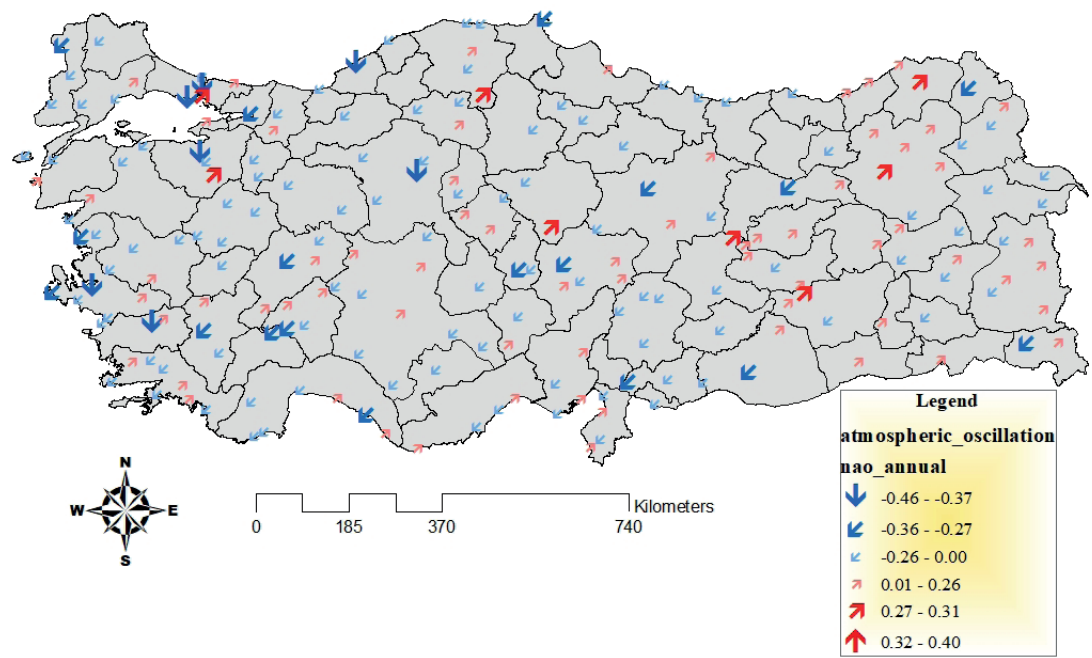

Correlation Between Long-Winter Nao and Stormy Days

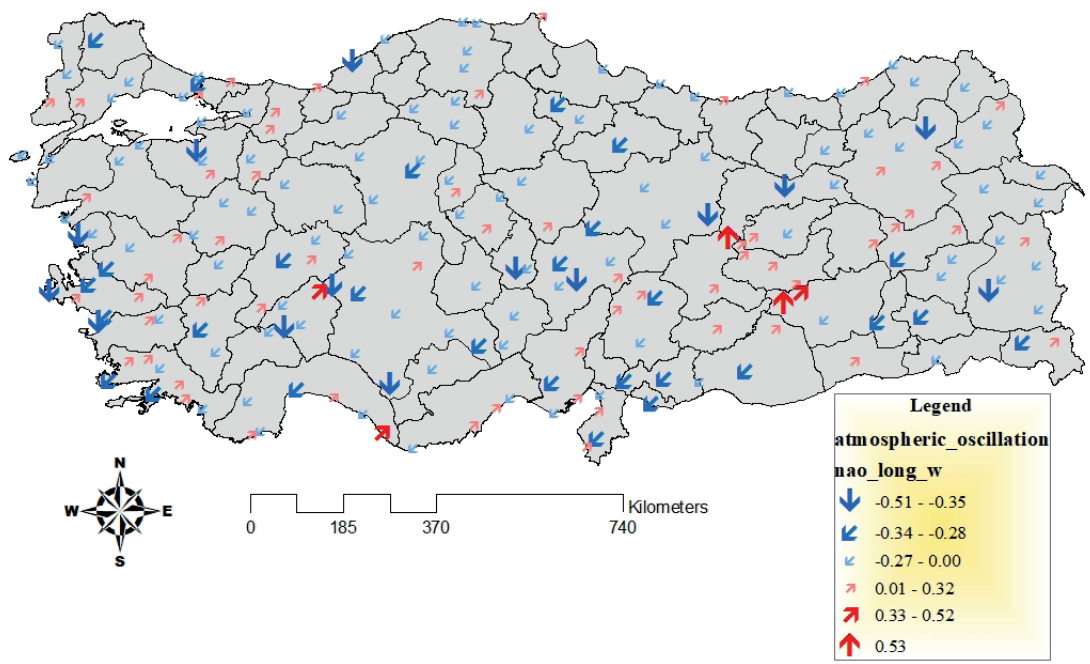

Correlation Between Winter NAO and Stormy Days

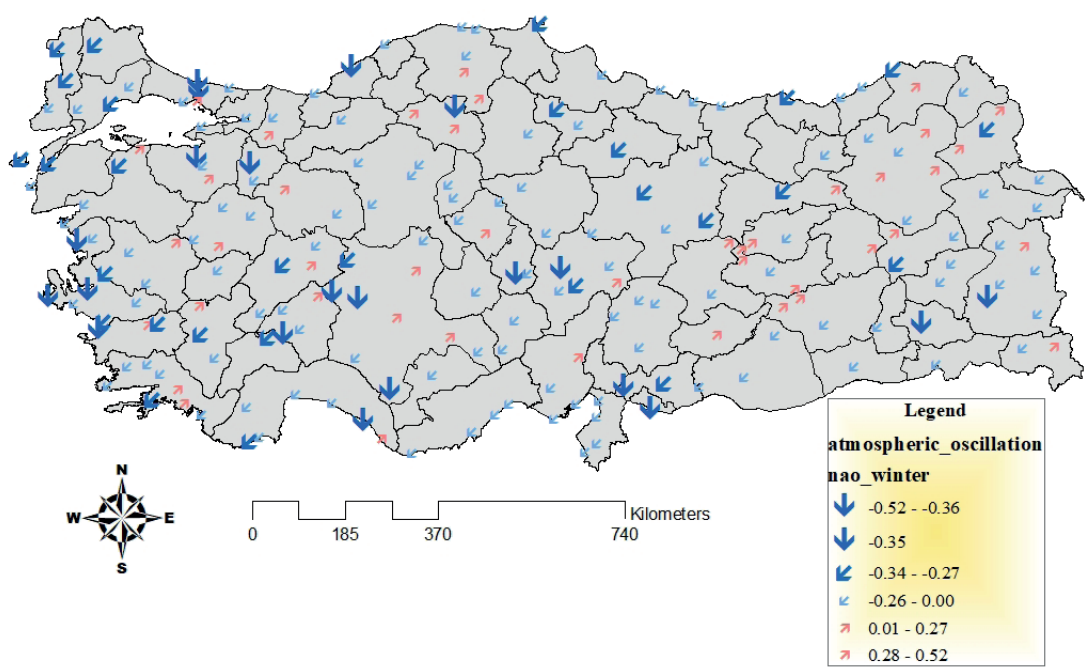

Figure 4. Correlations between NAO and Stormy days in Turkey. 


\section{Correlation Between Annual NCP and Stormy Days}

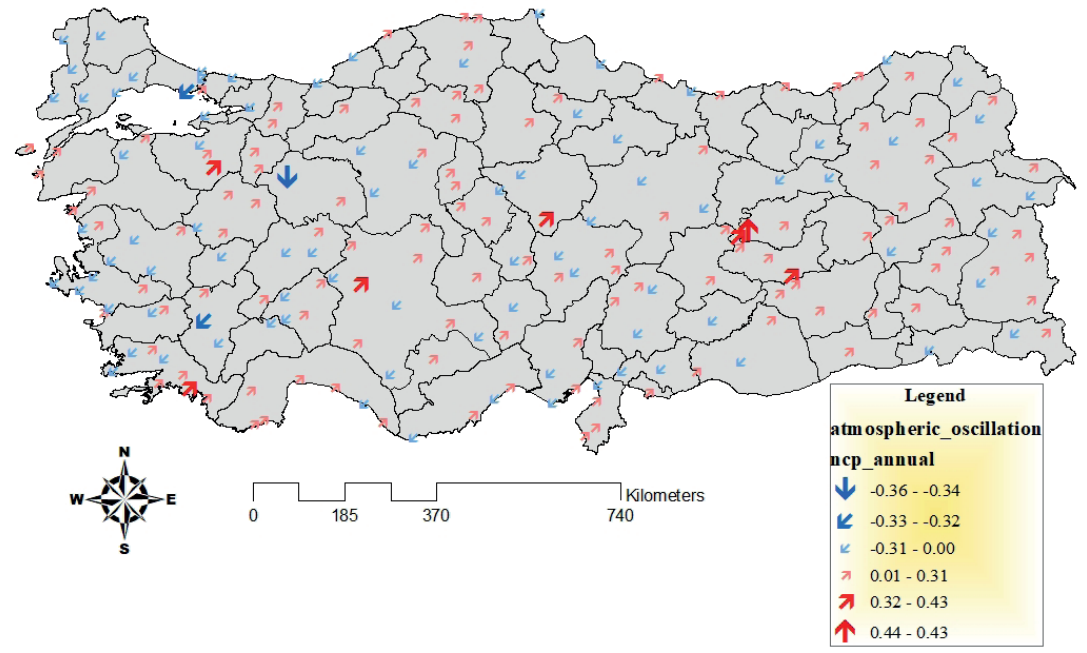

\section{Correlation Between Long-Winter NCP and Stormy Days}

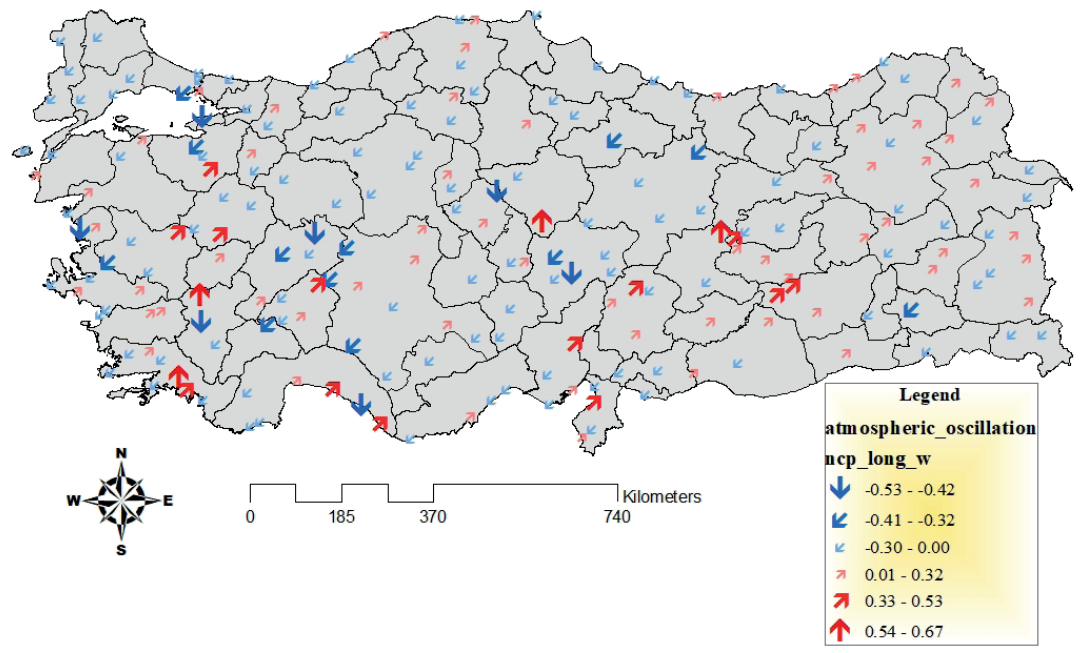

\section{Correlation Between Winter NCP and Stormy Days}

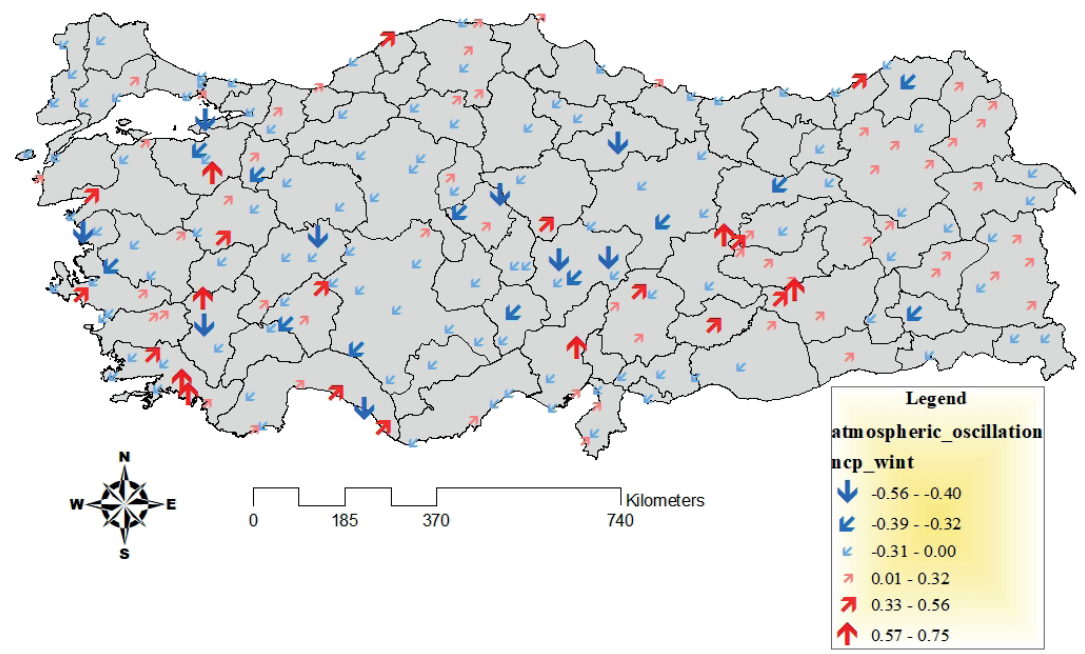

Figure 5. Correlation between NCP and Stormy days in Turkey. 
et al., 2002; Kutiel and Benaroch, 2002). Although the positive geopotential height anomaly (GHA) discrepancy (high in the North Sea and low in the Caspian Sea) and the positive NCP period usually relate to northwesterly winds in the area concerned, the negative NCP period corresponds to the southwesterly winds (Kutiel et al. 2002).

\section{Correlations between $\mathrm{AO}$ and storm}

The negative and positive phases of the Arctic Oscillation index affect winter temperatures in Turkey and air circulation over Turkey. In the positive phase of the oscillation, northern and northeast air currents dominate over Turkey, the Balkans and the Eastern Mediterranean. With these effective air flows, Turkey experiences below average temperatures in winter temperatures (Türkeş and Erlat, 2008). During the negative phase, Turkey temperatures were above average.The reason for this is the western and Southern Western air flows from the north of the Atlantic and Africa to Turkey and the Eastern Mediterranean (Türkeş and Erlat, 2008).

In Turkey, there is a statistically negative correlation between Arctic Oscillation and storm frequency in the western half of the country. During the negative phase of AO, there are increases in storm frequency along the western coast of Turkey. According to previous studies (Türkeş and Erlat, 2008; 2005) the effectiveness of the AO index on Turkey weakens after the winter season. Remote contact patterns better define storm occurrence at $\mathrm{AO}$ and NAO Turkey (Figure 6).

\section{DISCUSSION AND CONCLUSION}

The numbers of stormy days show a statistically significant increasing trend in the eastern part and inland Turkey. Statistically significant decreasing patterns of storm events are dominant in all of our coastal regions, especially in the western coasts and in the eastern Mediterranean continental areas. Consistency occurs between prior research and our test findings. There has been a tendency for calmer weather since 2000 (Valchev et al. 2012) in the research performed for the Western Black Sea, though changes in storm incidents were calculated before the 1980s and 1990s. Increases in stormy days became usually apparent from the 1960s to the 1990s, however after the 1990s calmer circumstances started to take hold (Alexandersson et al. 1998; Barring and von Storch 2004; Smits et al. 2005). Most stations in Turkey (73\%), $72 \%$ from 1975 to 2006 display a downward trend in average annual wind speed (Çelik and Cengiz, 2014).
In general, differences between regions are observed in trends of increase and decrease in storm frequency. There is no pattern which is statistically important in certain regions. This region is considerably lower than Turkey in general (Gökçeada, Iğdır, Giresun, Istanbul, etc.). The areas where there is a higher number of stormy days are strongly related to topography. The impact of topography on the high number of stormy days in areas like Çanakkale and its surroundings, the plain of Silifke and its surroundings, Elazig and its surroundings, Sinop and its surroundings is very determinative in this way.

There is a clear correlation between the spatial spread of storm occurrences in the Mediterranean area and topography, and a significant connection occurs in the Mediterranean area between precipitation and storm intensity (Galanaki et al., 2018). It is shown that the amount of stormy days in and around the Datça peninsula, where the Mediterranean coastal zone has a strong precipitation rate, is higher than the other less rainy areas of the Mediterranean region.

Data from the $\mathrm{NAO}, \mathrm{AO}$, and $\mathrm{NCP}$ were used in this analysis, analyzing relationships with stormy days and remote atmospheric indexes. Negative correlations were statistically dominant during the winter, particularly in stormy days all over Turkey with the NAO. The NAO is the index that most effects stormy days in Turkey during the winter season.Our findings are in line with Stroe and Tatui (2005). The NAO is in a negative phase declining southward to more western structures in Turkey and the Mediterranean basin and strengthening the impact of wind action in this region, and storm events in this region. Therefore, there is a significant link with the NAO storm occurrences in Turkey and the immediate area (Romania and Syria). There is a significant negative connection between Turkey's amount of stormy days and AO's. The effects of the similarities with the AO and NAO are close.

The NCP release correlates with Turkey with the amount of stormy days that are compatible with the findings of studies carried out in the local region. There is a significant positive relationship between NCP and the number of stormy days in eastern Anatolia and Northeast Anatolia. It is controlled by a trough in the upper atmosphere that developed during the positive NCP years in Northern Cyprus and the Eastern Mediterranean. Because of the intensification of the wind, the trough that settles in this area causes a positive course of storm events (positive correlation) in the region. In areas below the ridge area, wind speed decreases, and storm events (negative correlation) in these areas also weaken. 


\section{Correlation Between Annual AO and Stormy Days}

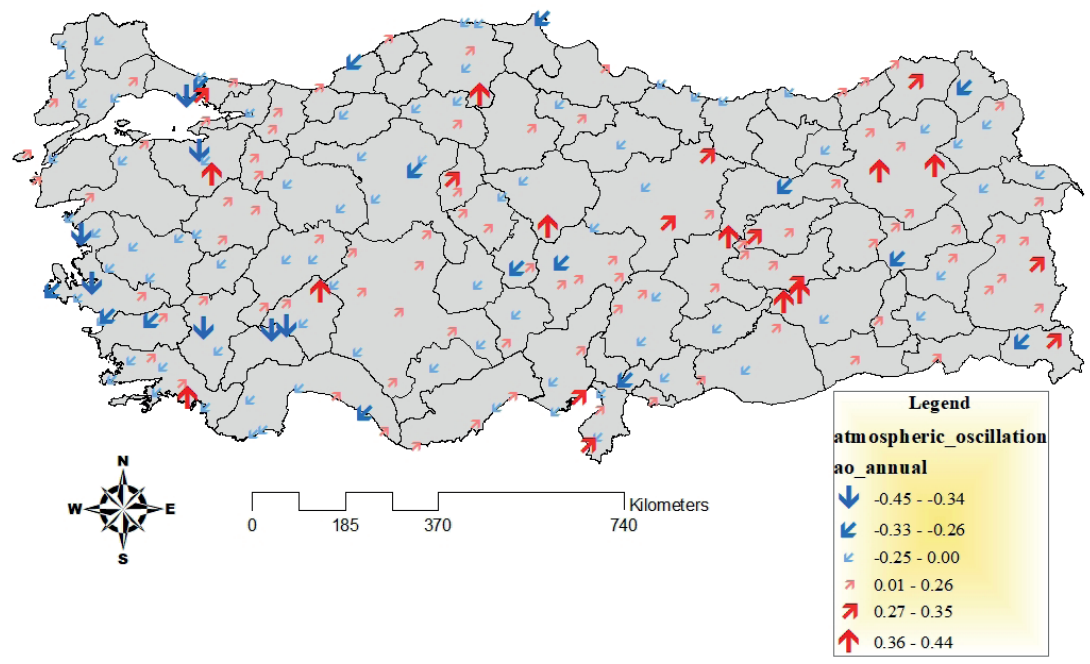

Correlation Between Long-Winter AO and Stormy Days

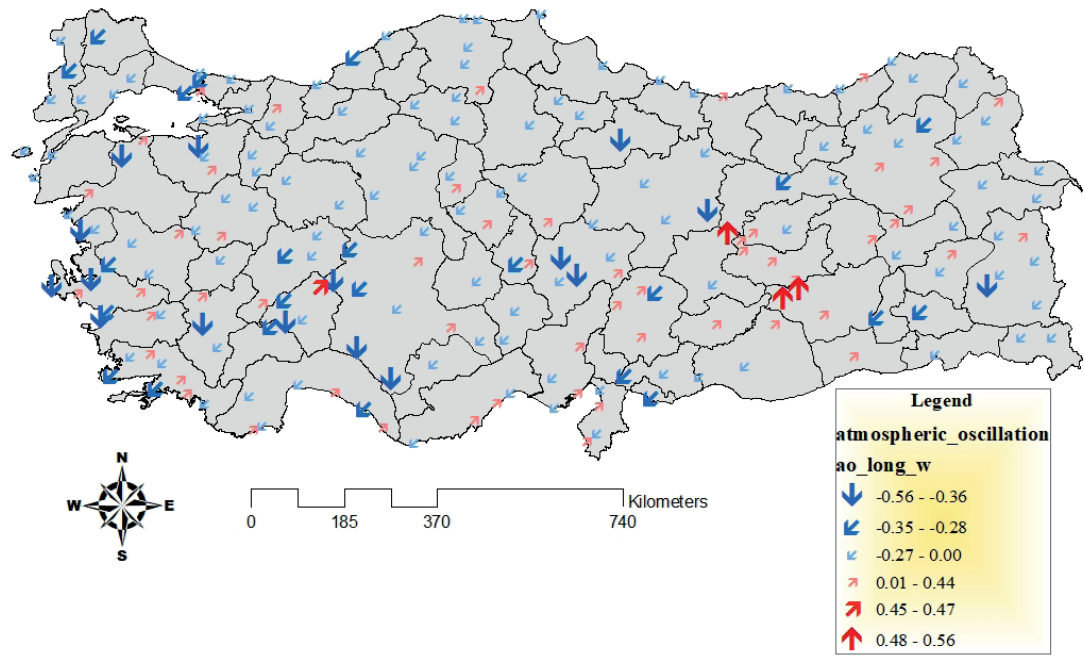

Correlation Between Winter AO and Stormy Days

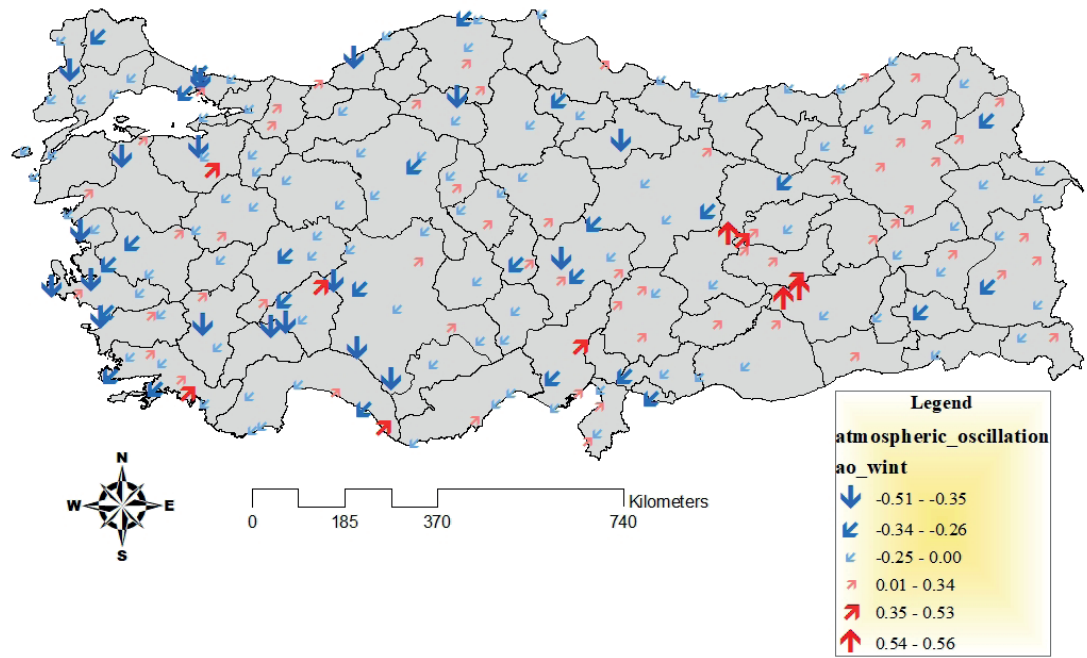

Figure 6. Correlation between AO and Stormy days in Turkey. 
Temporal variability and spatial distribution of stormy days; 1-geographical location characteristics of stations, 2- global climate change, 3-remote connection patterns have effects. Many parameters such as local variability or change in land use, temporal variability in climatic elements, effect of topographic structure, change of sea surface temperatures are effective on storm frequency. Therefore, it is necessary to consider multiple parameters when interpreting temporal and spatial variability for storm events in a region or area.

Analysis of correlations of the number of stormy days in Turkey with remote connection patterns showed that the indices that best explain the variability in the number of stormy days throughout the country are the NAO and AO.

Acknowledges: We acknowledge the Turkish State of Meteorological Office for providing the daily wind data

Peer-review: Externally peer-reviewed.

Conflict of Interest: The authors have no conflict of interest to declare.

Grant Support: The authors declared that this study has received no financial support.

Hakem Değerlendirmesi: Dış bağımsız.

Çıkar Çatışması: Yazarlar çıkar çatışması bildirmemiştir.

Finansal Destek: Yazarlar bu çalışma için finansal destek almadığını beyan etmiştir.

\section{REFERENCES/KAYNAKÇA}

Alexandersson, H., Schmith, T., Iden, K., \& Tuomenvirta, H. (1998). Long-term variations of the storm climate over NW Europe. Glob Atmos Ocean Syst, 6, 97-120.

Alpert, P., Osetinsky, I., Ziv, B., \& Shafir, H. (2004). Semi-objective classification for daily synoptic systems: application to the Eastern Mediterranean climate change, International Journal of Climatology, 24, 1001-1011, doi:10.1002/joc.1036.

Bacanlı, Ü., \& Tuğrul, A. (2016). Baraj göllerinin iklimsel etkisi ve Vali Recep Yazıcıoğlu Gökpınar baraj gölü örneği. Pamukkale Üniversitesi Mühendislik Bilimleri Dergisi, 22(3), 154-159.

Bakowska, Z. B. (2003). Long-term variability of thunderstorm occurrence in Poland in the 20th century. Atmospheric Research, 67(68), $35-52$.

Baltacı, H., Akkoyunlu, B. O., ve Tayanç, M. (2017). Türkiye iklim uç değerlerine uzakbağlantı paternlerinin etkisi. VII. Ulusal Hava Kirliliği ve Kontrolü Sempozyumu, Hava Kirlenmesi Araştırmaları ve Denetimi Türk Milli Komitesi, Akdeniz Üniversitesi Mühendislik Fakültesi Çevre Mühendisliği Bölümü, Antalya.

Barring, L., \& Von Storch, H. (2004). Scandinavian storminess since about 1800. Geophysical Research Letters, 31, L20202, doi: 10.1209/2004GL020441.
Bulut, H., Yeşilata, B., \& Yeşilnacar, İ. (2008). Trend analysis for examining the interaction between the Atatürk dam lake and its local climate. International Journal of Natural and Engineering Sciences, 1(3), 115-123.

Çelik, F. D., \& Cengiz, E. (2014). Wind speed trends over Turkey from 1975 to 2006. International Journal of Climatology, 34, 1913-1927.

Donat, M.G., Leckebusch, G.C., Pinto, J.G. \& Ulbrich, U. (2010). Examination of windstorms over central europe with respect to circulation weather types and NAO phases. International Journal of Climatology, 30(9), 1289-1300.

Galanaki, E., Lagouvardos, K., Kotroni, V., Flaounas, E., \& Argiriou, A. (2018). Thunderstorm climatology in the Mediterranean using cloud-toground lightning observations. Atmospheric Research, 207, 136-144.

Ghasemi, A. R., \& Khalili, D. (2008). The effect of the North Sea- Caspian Pattern (NCP) on winter temperatures in Iran. Theoretical and Applied Climatology, 92, 59-74.

Gündüz, M., \& Ozsoy, E. (2005). Effects of the North Sea Caspian pattern on surface fluxes of Euro-Asian-Mediterranean seas, Geophysical Research Letters, 32, L21701. doi:10.1029/2005GL024315.

Hurrel, J.W. (1995). Decadal trends in the North Atlantic Oscillation: regional temperatures and precipitation. American Association for the Advancement of Science, 269(5224), 676-679.

Hurrel, J. W., Kushnir, Y., Ottersan, G., \& Visbeck, M. (2003). An overview of the North Atlantic Oscillation: climatic significance and environmental impact. American Geophysical Union, (s.1-36), Washington, DC.

Hurrel, J. W., Kushnir, Y., \& Visbeck, M. (2001). The North Atlantic oscillation. American Association for the Advancement of Science, 291(5504), 603-605.

IPCC. (2007). The physical science basis: summary for policymakers contribution of working group I to the fourth assessment report of the Intergovernmental Panel on Climate Change (IPCC), IPCC Secretariat, WMO, Geneva.

Kendall, M. G. (1975). Rank correlation methods. Charles Griffin: London.

Kurtuluş, Y. F., \& Acar, Z. (2019). Spatial and temporal variability of the stormy day in Turkey. Ístanbul International Geography Congress, (s.1182-1190). İstanbul.

Kutiel, H., \& Benaroch, Y. (2002). North Sea-Caspian pattern (NCP)-an upper-level atmospheric teleconnection affecting the Eastern Mediterranean: Identification and Definition. Theoretical and Applied Climatology, 71, 17-28.

Kutiel, H., Maheras, P., Türkeş, M., \& Paz, S. (2002). North Sea-Caspian pattern (NCP)-an upper-level atmospheric teleconnection affecting the Eastern Mediterranean-implications on the regional climate. Theoretical and Applied Climatology, 72, 173-192.

Kum, G. (2016). The influence of dams on surrounding climate: the case of Keban Dam. Gaziantep University Journal of Social Sciences, 15(1), 193-204.

Mann, H. B. (1945). Nonparametric tests against trend. Econometrica, $13,245-259$. 
Maheras, P., Flocas, H., Patrikas, I., \& Anagnostopoulou, C. (2001). A 40 -year objective climatology of surface cyclones in the Mediterranean region: spatial and temporal distribution, International Journal of Climatology, 21(1), 109-130. doi:10.1002/joc.599, 2001.

Marcos, M., Jordá, G., Gomis, D., \& Pérez, B. (2011). Changes in storm surges in southern Europe from a regional model under climate change scenarios. Glob Planet Change, 77(3-4), 116-128.

Matulla, C., Schoner, W., Alexandersson, H., von Storch, H., \& Wang, X. L. (2008). European storminess: late 19th century to present. Climate Dynamics, 32, 125-130.

Nissen, K. M., Leckebusch, G. C., Pinto, J. G., Renggli D., Ulbrich, S., \& Ulbrich, U. (2010). Cyclones causing windstorms in the Mediterranean: characteristics, trends and links to largescale patterns. Natural Hazards and Earth System Science, 10(7), 1379-1391. doi: https://doi.org/10.5194/nhess 1013792010

Qu, B., Gabric, J. A., Zhu, J., Lin, D., Qian, F., \& Zhao, M. (2012). Correlation between sea surface temperature and wind speed in Greenland Sea and their relationships with NAO variability. Water Science and Engineering, 5(3), 304-315.

Raible, C.C., Saaroni, H., Ziv, B., \& Wild, M. (2010). Winter cyclonic activity over the Mediterranean Basin under future climate based on the ECHAM5 GCM, Climate Dynamics, 35, 473-488. doi:10.1007/ s00382-009-0678-5

SANHO, (2009). South African Tide Tables. Tokai: Naval Hydrographer, South African Navy Publishing Unit. ISBN 97809584817-4-8.

Smits, A. K., Tank, A. M. G., \& Onnen, G. P. K. (2005). Trends in storminess over the Netherlands, 1962-2002. International Journal of Climatology, 25, 1331-1334.

Stroe, A. V., \& Tatui, F. (2005). The influence of North Atlantic Oscillation on Romanian Black Sea coast wind regime. Analele Univ Buc Seria Geografie, 54, 17-25.

Stroe, A. V., \& Tatui, F. (2011). North-Atlantic Oscillation signature on coastal dynamics and climate variability of the Romanian Black Sea coast. Carpathian Journal of Earth and Environmental Sciences, 6(1), 309-316.
Türkeş, M. (1996). Spatial and temporal pattern analyses of rainfall variations in Turkey. International Journal of Climatology, 16, 1057-1076.

Türkeş, M., \& Erlat, E. (2005). Climatological responses of winter precipitation in Turkey to variability of the North Atlantic Oscillation during the period 1930-2001. Theoretical and Applied Climatology, $81,45-69$.

Türkeş, M., \& Erlat, E. (2008). Influence of the Arctic Oscillation on variability of winter mean temperatures in Turkey. Theoretical and Applied Climatology, 92, 75-85.

Türkeş, M., \& Şahin, S. (2018). Türkiye'nin firtına afeti etkilenebilirliği ve risk çözümlemesi. Kebikeç, 46, 219-246.

Trigo, I. F. (2006). Climatology and interannual variability of stormtracks in the Euro-Atlantic sector: a comparison between ERA-40 and NCEP/NCAR reanalysis. Climate Dynamics, 26, 127-143, doi: 10. 1007/s00382-005-0065-9

Unal, Y. S., Deniz, A., Toros, H., \& Incecik, S. (2010). Temporal and spatial patterns of precipitation variability for annual, wet, and dry seasons in Turkey. International Journal of Climatology, 32(3), 392-405. doi: 10.1002/joc.2274

Valchev, N. N., Trifonova, E. V., \& Andreeva, K. N. (2012). Past and recent trends in the Western Black Sea storminess. Natural Hazards Earth Systems, 12(4), 961-977.

Xoplaki, E. (2002). Climate variability over the Mediterranean. $\mathrm{PhD}$ dissertation. University of Bern, Switzerland.

World Meteorological Organization. (2016). Manual on codes, international codes, Vol I.1 Annex II to the WMO technical regulations part a-alphanumeric codes, WMO No. 306, ISBN 978-92-63-10306-2.

World Meteorological Organization. (2013). The global climate 20012010 a decade of climate extremes, WMO-No. 1119, ISBN 978-9263-11119-7. 
